\title{
Breconshire Village Folklore.
}

\author{
M. E. Hartland \& E. B. Thomas
}

To cite this article: M. E. Hartland \& E. B. Thomas (1913) Breconshire Village Folklore., Folklore, 24:4, 505-517, DOI: 10.1080/0015587X.1913.9719586

To link to this article: http://dx.doi.org/10.1080/0015587X.1913.9719586

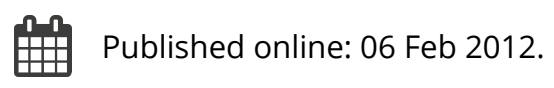

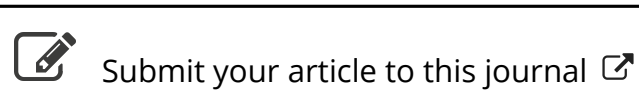

Q View related articles $₫$

4 Citing articles: 1 View citing articles 죽 


\section{Breconshire Village FolkLore.}

Most of the tales and old sayings related below by Miss E. B. Thomas of Llanthomas, Llanigon, were told to her, exactly as given, by Anne Thomas, wife of the gardener of Llanthomas, a native of Llanigon, who died in 1905 , aged $8 \mathrm{I}$ years.

Llanigon is a parish in the county of Brecon, and extends from the summit of the Black Mountains almost to the banks of the Wye. The range of the Mountains separates it from Monmouthshire, and Herefordshire forms another boundary. The two nearest towns, Hereford and Brecon, are each about 18 miles away. The land is entirely agricultural, cut up into small farms, which become sheep-runs on the higher slopes of the mountain. The village is a cluster of houses around the church and school. The population has decreased from 596 in 1821 to 323 in 1911 . As might be expected, education is very backward, owing to the isolated position of the houses and the distance which many of the children have to come to school. The Welsh language has not been spoken for nearly a hundred years, although the inhabitants have all the physical and mental characteristics of the Welsh people, and the names of the places are universally Welsh or of Welsh origin,- such as "Wenallt" (white height), "Tymawr" (great house), "The Celyn" (holly), "Penlan" (the high place), "Maesygarn" (meadow of the cairn), etc. It has been claimed that Llanigon is derived from "Llan" (a church) and "Eigen," daughter of Caractacus, who is said to have lived at the close of the first century at Trefynys, (now Llanthomas). There is a well at the end of Mr. Connop's workshop, not far from the church, called still St. Eigen's well.

Superstition dies very slowly in the place. The laws now prevent tampering with graves, so that the several forms known of "laying a ghost" are no longer practised. Miss George told me that this could be done by turning the corpse in its coffin with the face downwards. There seemed a general belief that the ghost of Joseph Arndell troubled the parish. His tombstone is in the churchyard, and inscribed "Joseph Arndell, died Aug. 27, 1768, aged 60 years." During his life he had the reputation of being an unbeliever, and spent his Sundays in irrigating his property of 
Penywrlodd. Six neighbouring clergy therefore met after his death, armed with candles and books, "to read him down." A form of spell was read to bring the ghost to the spot. It arrived in the form of a bellowing bull, which frightened five of the parsons into fainting-fits. The sixth continued his incantation, whereupon the bull dwindled in size. "Why are you so fierce, Mr. Arndell?" said the parson. "Fierce I was when I was a man, but ten times fiercer now that I am a devil," replied the bull. The ghost continued to dwindle in size until it became as small as a fly. Whereupon the parson secured it in a box, and threw it into a well in the wood above Penywrlodd. Then the parish had peace. ${ }^{1}$

- On the banks of the brook Cilonow a tall plant of medicinal properties, with large yellow blossoms, called Elecampane (Inula Helenium), grows in masses. An old woman selling salves in the streets of Brecon was heard to sing the following rhyme, about fifty years ago, by Mr. Jones, the farmer of Llanthomas, -

" Elicampane sy'n gwella i'r hen

Eli Trefynnon a'i gwella yn union

Eli Treflint a'i gwella yn gynt."

(Elicampane will cure the old.

Eli (the salve) of Trefynnon (Holywell) will cure directly.

Eli (the salve) of Treflint (the town of Flint) will cure sooner.)

The belief in charms is still universal. One person, however, usually claims only to have power over one, or perhaps two, diseases, and they all declare themselves powerless over rheumatic affections. Neither thanks nor payment in money are permitted. Faith on the part of the patient is the one thing required, and it is not always necessary that the patient should see the charmer. The spell may be exercised if the name and description of the person and of the disease be given. A gift in kind generally finds its way to the home of the charmer later on. Williams, a gardener who has been for some years in America, told me that he got rid of 150 warts by stealing a piece of meat, rubbing the warts with it, and then burying it. The warts disappeared within six months. He was cured of hernia by a man named Alcott, although a doctor (whose name he gave) had failed to cure him. This man

${ }^{1}$ Rev. W. E. T. Morgan, Transactions of the Woolhope Club, 1898, p. 39. 


\section{Collectanea.}

rubbed the place, repeating the Lord's Prayer. A trussed chicken was despatched later to Alcott's house.

Williams also claimed to have the power of finding water with the aid of a hazel stick. He said that he found water for two farmers in America, and that this nearly resulted in a lawsuit. When the second farmer sank his well, the water from the first farmer's well disappeared. On investigation, it turned out that water from the same source supplied both wells.

Mr. Phillips, wheelwright, of Brookside, Llanigon, claimed to have cured Alice Lewis' toothache by giving her the following charm to wear round her neck:- "As Peter stood at the gate of Jerusalem, Jesus saith unto him, "What aileth thee?" He said, "My teeth do ache." Jesus said, "Whosoever carrieth these lines about them, or beareth them in memory, shall never have the toothache any more, in the name of the Father, and of the Son, and of the Holy Ghost, Amen! and Amen! So be it according to thy faith. Alice Ann Lewis." " This written charm was brought to me by Mr. Connop, a son-in-law of Mr. Phillips.

I was told the names of several men now living,-James Greenhow, and Mr. Howells of Peterchurch, for example,-who claimed to have the power, and still exercised it, of stopping the flow of blood, and curing the sprained limb of an animal.

Crishowell was a cluster of houses in the parish, now in ruins.

\section{E. Hartland.}

\section{Crishowell People and their Nicknames.}

Above Brynglessy's house, right side of lane, "Old Birdie Peggy." A garden between two houses. Mrs. "Shake-rags" lived; four boys and husband. Well! then you go on up to top of Crishowell. There Mrs. Job [Sarah Evans] did keep shop. Then Hannah Thee lived next; five sons, three daughters, husband. You do go on to old Pally and old Nancy, and John her brother. (They was living together.)

Left was old Jenny Toulsin, and Jack Toulsin her husband, and one daughter. And old Toddy lived next; one daughter. Mrs. Hobby and husband lived next, more higher than old Toddy. And the next, Mrs. Perrett, and William Walker; her did keep a servant,-name Jane Dolly, of Dolly's Plock. Old Mrs. Perrett 
kep' Walker as a Bailie. Jenny Toulsin made an oven of clay to make bread, and, if it cracked, she would dab another wet lump on it; and Jenny Toulsin did make balls of wood-ashes to make lye to wash, and people did buy 'em of her. Mrs. Hobby was a lady, she kep' a school. She wore white satin shoes at the christening of Henry Prothero [Anne Thomas' brother].

There was old John Jones, and Jenny Jones, for his wife. Kitty Davies also. Betsy, Jenny Jones' daughter, married Toddy. He was a wicked man, because he cut down all the young birches and nut-trees on a Sunday. What sprigs were over, poor old Jenny would burn 'em and make nice white ashes. The children all about Crishowell sang this song about "The Green Jiner," as old Toddy was called. (The Green Jiner used to cut birches, and make whiskets and besoms.)

\footnotetext{
"On Crishowell the Green Jiner did dwell, By his neighbours he's known very well, Lying and canting, and kicking up strife, Beware of the Duke and the Duchess his wife!"
}

Old Sarah Evans, who kept the shop at Crishowell, did use the Blue-freestone from Crishowell quarry, and stone [i.e. draw patterns of] all manner of birds, and old women, and strokes, and diamonds.

There's a noted well at Crishowell, called "The Stockett Well." There is no well there now, I doubt! There was a Pound at Crishowell.

\section{Moll Toot.}

There was Moll Toot. She lived up the village, where Lettice Bowen used to. She made an agreement with her husband before she married him that she would never do a single thing for him; no more she did. She used to wear a very large poke bonnet, covered over with black silk which had got grey with age; it was nearly as big as an umbrella. The poke was nearly half a yard long in front, and the head at the back was long, like a man's hat, and touched the poke in front. Her hair was sandy and twisted in loops in front. She had a neat little white cap on all round the face, and a white muslin handkerchief tied across in front. She wore a yellow buff dress, and always had bright polished shoes 
tied with string, and she wore pattens if it was the driest day in summer. She always kept a brush in her pocket for the purpose of keeping her shoes bright, and when any one passed her door she always shook a white cloth after them, to shake off the dust. She was always a neat little body.

\section{Sayings.}

Them as do wear a hole in the middle of the shoe, they'll never want bread.

He is a lawyer! As sharp as a needle with two points.

The boldest person is the one that gets on in the world the best; they didn't use to; they have no dew on their tongue.

Of a little take a little, for you're welcome to, Of a little leave a little, 'tis manners so to do.

There's plenty of mushrooms for an old song now.

It do fill their eyes just for a moment, and something will come and take it away, [said when damsons were stolen].

A galloping horse will see no hole in it, [said of an old shawl with holes in it].

It's a sorrowful wind that'll blow nothing.

The Radnorshires are peacocks when they come, but like pigeons at home, [said of Radnorshire people].

Price of the Wenallt did say,- "I trod on a lucky stone when I come over the Wye."

Once good, twice bad.

Never push a man when he's going down the hill.

He who takes what isn't his'n, when he's cotched is sent to prison. [Almost universal in England.]

Mrs. L. of Llanigon village met Mrs. M. and saw she had a red flower in her hat, and told Mrs. M. to take it out, saying, - "We belong to the Mothers' Union, and must dress quietly. You are like an ould yow dressed lamb-fashion." [A Yorkshire saying.]

A rum old saying, but I believe it is true,-" "Them as isn't to do, shan't do!" I can prove it to be true I If I do sit up late and rise yarly, and work an the hours the Lord have sent for me, I shall never get rich. I've read that in the Tracts too, and mother did say if her did get up to three-pence halfpenny, her 
was back to threepence, her never could get to a groat. Her'd lose a caulve or something.

She must have the bean for the pea, [in bargains].

She would skin a fint, and spoil a sixpenny knife by it.

Down with the lambs, up with the lark,

Run to bed, children, before it is dark !

Out of the fashion, out of the nation.

A dainty little dame,- you canna touch her with a hop-pole !

A rotten chip can run downhill easy enough, but coming back is the main!

I wonder what they are doing in London to-day, for we are very busy here.

When any one is slow and don't look sharp, it is "Jack behind Mary !"

The folied [foolish people] from Capel-y-ffyn did go out with bags to catch the moon. They said it was a cheese.

Anne Prothero and her brothers and sisters used to say of a peony,- "The ould hen is dropping her feathers."

A good contriver is an early riser.

A little help is worth a lot o' pity.

A timber-man [who loads a timber-waggon] has never need of a lawyer to make his will.

I must speak well of the bridge as do carry me safe over,-like the old man said.

Nothing is too hot or too heavy for a thief.

He that will steal a pin will take a bigger thing. [Universal.]

Keeping $a$ [servant] girl and finding her food, that'll take the shine out of the gingerbread.

It is the yarly crow ${ }^{2}$ that eats the late un's breakfast.

She'll do where the crows do starve.

Where there are three children,-two to fight, and one to part 'em,- - that's nice.

Whatever is young learnt is never old forgot.

The cold wind in March was called Heirloom. There was a man went to a cottage to ask for a bit to eat, and she said she had a bit of cheese in the house. Her husband had kep' it for Heirloom. The man said,- "My name is Heirloom." The poor

2 Pron. to rhyme with row (a quarrel). 
woman was took in, a bit. The husband was keeping it for bad weather.

I should think we should have no more snow, unless it is some lamb-snow, [meaning snow coming in April].

When the mist is hanging up on the Allt wood, the children used to say,- - Old Rhys [of] the Bwlch is boiling his pot, and it will soon boil over."

The sun and the wind do meet at three o'clock. [Sign of rain.]

New Year's tide, the days lengthen a cock's stride.

Candlemas Day, all candles away.

Where the wind was on the 2 Ist of March, there it would be till the 2 ist of June.

Ould March is never out till the 12 th of April.

A cold May makes a full barn.

If her [missel-thrush] do sing in January, her'll cry afore May.

The first cock of hay, the cuckoo goes away.

I went away on Michaelmas Day,

And left my barn full of corn and hay.

I came again at May,

And it was all cliterdy, cloterdy, all gone away! (Of the swallow.)

Never come Lent, never come winter.

The wasps leave their nests on the 26th of August.

December, the dark month afore Christmas.

Plant and prune,- the increase of the moon.

"I love to marry while the bloom is on my face." Girls used to say that. "She have left the sun gone over the hill."

You mustn't tread hard on a bear's foot, else er'll turn on you by and by, [said of a wife keeping away from her husband too much].

\section{Funeral Custom.}

When the mother-in-law of Mrs. Lewis of the Celyn was buried, - she lived in a funny old house on the left-hand side before you go to the bridge beyond Celyn, - they was pulling the plum-cake out of the oven, which was out of doors, and breaking lumps and giving it to everybody. Anne Thomas was then a tiny girl, and had a piece given her which she dropped, as it was too hot, but afterwards put it into her pinafore. 


\section{Flowers.}

The Rose de Meaux was all over picks [thorns]. Anne Thomas" mother used to say to the children,-- "Don't you touch that rose. It killed one lady." A young lady had the choice of three husbands to marry, and she wouldn't do as her father did wish her, so he did put the gardener to choose for her. The gardener said,"I will choose you the violet, the lily, and the pink." (She had one in her eye besides those three.) Then she said,- "I refuse the three, but in June the red rose buds, and that is the flower for me. The willow-tree did twist and the willow-tree did twine, and I wish I was in the arms of the young man that has the heart of mine." She married him, but he wasn't good to her. She wasn't happy, and so she died.

An old carpenter named Phillips, who died in 1903 , told me that old people call monkshood "mother's nightcap," and the corn blue-bottle (centaurea cyanus) "devil-in-the-bush "-(his body surrounded with scales, the scales of the old serpent, brimstone torches, plain enough too I And his brazen face in the midst !)

\section{Calendar Customs.}

Rhymes sung at the New Year:-

New's gift, New's gift,

I wish you merry Christmas and a happy New Year.

A pocket full of money, And a cellar full of beer,

A good fat pig to last you all the year!

The roads are very muddy, My shoes are very thin,

I've got a little pocket to put a penny in.

If you've not got a penny, a ha'penny will do.

If you've not got a ha'penny, God bless you !

The cock is in the holly-bush, the hen came clucking by.

Please give me a New's gift, or a Christmas pie.

May Day.-When Anne Thomas was a lump [good-sized child], the oak-boughs was by the Swan. Boughs was put up each side the door, two sprays, and above the porch. Spillman was there then. The same thing was at public-houses up the street. "Agin the First of May," old women, and Anne Thomas' mother, and even herself, ran about after whittun-tree [mountain ash] and 
birch, and put it above every door, even the beast house, to keep the witch out; and every outside must have a bit of a sprig. At the works in Llanigon parish there would be a large tub of water, with rosy-cheeked apples in; and boys had to try and catch them.

Harvest.-Stephens of the Sheephouse used to try and get his wheat in before others had hardly begun, and gave his men bottles of drink to go on the Tump above Penglommen and holloa "Harvest home!" About ten men went after the first load was brought in, and they'd echo the whole parish, shouting "Harvest home!" If the last load did slip, there was no goose for the men's. dinner.

Parsnip Day.-William Thomas called the twenty-first day of December "Parsnip Day," and remembers, when he was a boy, his mother always gave them parsnips on that day. It was an old Welsh custom. Mrs. Davies remembered an old aunt of hers always had parsnips on Parsnip Day.

Llanigon's Feast.-This Feast took place on the first Sunday after the 2oth of September. Farmers 'ud give milk on Saturday in earthen jars, according to what they could spare. At Pot Street (village lane) there was a biggish arch, going down to the two houses, and a big oven facing the road; two women 'ould bake in it at a time, and heps of rice puddings and apple tarts were made there agin the Feast, and if you had any ducks before the Feast, they was gone, unless they was locked up. The blacksmith's shop was then a public, and seats were all round the wych-elm there, and a table with drink, and a woman would come up with cakes and nuts from Hay, and sell them. All this went on on a Sunday. Cakes and nuts were sold again on Monday. Young people mostly came on the Sunday, and every servant would come home to the Feast. On Monday night farmers and married people would go and dance,-old Betty Humphreys and old Rhoda Newell ; the latter would bring servant-fellers from Court O'Llowes. People would come from the two publics, and begin to wrestle and fight. The orchard at the blacksmith's shop was just full with men. At one fight old Nancy Walker carried her husband a quart of beer, and said,_- "Fight on, Jack, I'll carry thee bones home in my apron, before thee be beaten."

Old blind Ukin played the fiddle at these Feasts for the people to dance, and his daughter did carry it and often played at the 
Swan. A blind harper from the Harp at Glasbury played the harp also at these Feasts, and carried it by a string on his back.

\section{Dances.}

Quarterly dances in Llanigon parish took place in the time of Anne Thomas' mother. "It did go round. Mother was at the old Veralt-house by Pencaecock. She was there at a dance. There was young people going there. Old Tom Masta did fasten the door, as they couldn't come out. There was a window, but no cagement. He was angry, because his sweetheart was there. Him did holloa,-_"Herrings for breakfast to-day!" Some one let them out.

Four or five places they had dances in,-Cilcovereth one, Llwynmaddy, "The old Veralt," The old Public. For the dance, six men one side, six girls the other. In the dance, "Haste to the Wedding," old blind Ukin stamped his feet. "Up the middle and down the sides," he said. The girls had short-sleeved frocks, and arms as red as roses, and frocks half-way down the leg. They had low-necked dresses with a white handkerchief under, up to the neck. For the dance Anne's mother and all the women wore bob-tail dresses, two breadths, and tied up behind, in a bob-tail, and a good petticoat to show, which cost more than the dress. All married people would go on a Monday evening to the dance, but wait till old Mrs. Lewis, [of ] the Celyn, did come down to open the ball,--sometimes with old Rhoda, who was then young and smart. Old Mrs. Lewis used to dance on her toes. Miss Lewis was a lump then, - ten or twelve years old. It was like the rule of the country: they must all go to the Monday dance. They had "Bonnets of Blue," "Swansea Hornpipe," and "The Cushion Dance." For this last one, a young man and a young woman kneeled down on the cushion, and kissed one another before every one, and they always locked the door, else the girls would be running out. The fiddler would lock the door to have his sixpence or threepence all round. For the "Bonnets of Blue," it was "Hays-round, three turns round, and gig-like." Old Nancy Walker used to come in and say,-_ "Hooray for the Bonnets of Blue!" The old fiddler did stamp his feet, and say,- "A cross out and a figure in, and round me and back again." 
Custom when some old women got behindhand with their rent. "An old widow, say Mary Jenkins, would come round we servants at the farm-houses, and ask we to come and have a cup of tea at one shilling apiece, servant-girls and servant-men, and bring the whistle-pipes, and dance after our tea. Then they'd count the money up, and see if enough to pay rent, and, if not enough, they would go round and say,-_" Sixpence, please." And some would have shaking dice for a couple of fowls. They was jolly good servant-men in those days. Some married people would come too, to help the ole woman on,-Nancy Walker and old Betty Hemp, from Cilcovereth. At Llwynmaddy there would be a teaparty. There was a tea-party at Fforddlas at Jones' (Tregoyd bailie's) house, where Mrs. Bounds lived, and they did bring nine gallon of beer there. Betty Hemp had a bottle of gin, and they gave her a sixpence apiece for some; her husband was always making hemp; he was called Harry Hemp. A dozen places tea would be at. They would have a bit of plumcake hot out of oven, , and bread and butter.

Fairies.

When Anne Thomas was a girl, the children and she were all warned never to go inside a fairy-ring. "When we was going to school, in the Celyn's meadow, there was fairy-rings, and grandfather did say we must mind and not put our foot inside the fairy-rings, else the fairies would have us. And we was afeard in our heart to put our foot inside, afeard the fairies would get hold of we. And they said there was music and dancing and fiddles at night. A man did come home from the Hay fair, drunk, and had cakes in his pocket; and, hearing the music, he stepped in the ring to them, and there he danced. And he would not tell how many years he had been inside there. And when he came out he came to where he thought his home was, and they was all gone, and there was no-one there."

\section{Folk-Tales.}

Story of old Tyucha.-Old Tyucha, ${ }^{3}$ as she was always called, lived at Graswell. She used to go to the market at Hay, so had

Ty ucha (the upper house) was the place where the old lady lived, not her personal name. It is quite common in Wales to speak of a person by the name of his residence. 
to pass the Boiling Well. She always came with a tall stick in her hand. She used to wear an old close-fitting calico cap, and the border did come to pin under her chin, and a sort of a straw hat on her head. She always came to Hay in a greatcoat with a cape on it, and used to wear a shawl over her shoulders as well in the winter. The hair of the horse used to come off on the greatcoat; no skirt was seen. Old Tyucha had to pass the Boiling Well, where the spirit was always to be seen, dressed in white. She always left Hay in good time, so as not to pass the Well when it was dark, for fear she should see the spirit. The white lady used to jump on her horse with her at the Boiling Well till she did ride to her own house with her. Then she did lose her at once.

Story of Stoke Edith.-Two ladies wished to buy Stoke Edith, and could not decide, so got two wood-lice and put them to race together on a table. One lady tried to push on hers with a pin. to win the race, but the wood-louse turned over on its back, so the other won the Stoke Edith estate. They kept a clown,-Will-foola-ham,- to amuse them, and he used to swing up and down on a tree-bough over a pool of water. And one day the carpenter sawed nearly through the bough, so that, when the clown got on to amuse the people, he fell into the pool, and was so angry he determined to revenge himself. He went on when the carpenter was asleep, and caught hold of an axe and cut his head off, and said "he did not know where the carpenter would find his head when he awoke, as he had hidden it in the shavings." Then he hid himself in a bolting of straw. And the pursuers came after him, and one called out,- " I can see you, Will," and he said,"You are a liar, you can't!" Then they collared him, and took him before the judge. But they could make nothing of him, and thought him out of his mind. And the judge ordered one of the warders to reach him a knife, and said,- "Hand me that knife, my man," and he pushed the blade at the judge, and they judged him insane. And he saved his head!

Story of a Serpent at Mordiford (Herefordshire).-At Mordiford a serpent came out of the wood, and used to go to the river to drink, and people was afraid of him, and put a reward for anyone who should kill him: And one man volunteered to do it, and 
got into a logshead, and put the end back, and his gun through the small hole. And waited till he came, and shot him, but did not kill him outright. And the serpent put his venom into the hogshead, and killed the man. This happened about $15^{\circ}$ years ago.*

The Mouse and the Basin.-There was an old man breaking stone, and a gentleman did come by, and the man told him he was bound to work, as he had ten children to keep, and the gentleman asked him,- " How did 'er find a living for them all?" "By making much of the youngest always." "That is too hard a work for you. I will keep you." Well! then he said he should come away to his seat, and then he would send money for his wife and children. And, when the poor man came to the seat, the gentleman did charge him he was not to touch that basin. And the poor man did rise it to see what was under him, and off goes the live mouse, and the gentleman couldn't trust him, and then him had to go back to his stone again. ${ }^{5}$

\section{Miscellaneous.}

Ladybird.-Anne Thomas used to count the spots on a ladybird's back, to see how many years she should be married. IVilliam Thomas used to call it "Little Red Cow." As a boy he used to put one on his hand, and say,- "Are you going to fly, or are you going to fall?" If it flew away, it was going to be fine; if it fell, it was going to rain.

Marriage.-Young men wanting to find out the savingest wife did go and see all the kneading-troughs, and that one as he could find no waste on it, that was the savingest one.

Handsel._In selling a pig or something, say,-_" Please to give me a Honsal for luck. You must gie me a Honsal." Old Duffee used to say,- "If I'd give him a halfpenny, he'd be lucky all day, her'd sell." "I shall go well all day," her'd say.

'Cf. Mrs. E. MI. Leather, The Folk-Lore of Herefordshire, p. 24.

${ }^{5}$ Cf. J. Jacobs, More English Fairy Tales, p. Iog. 